\title{
HUBUNGAN TINGKAT KECEMASAN DENGAN PENINGKATAN TEKANAN DARAH PADA PASIEN PRAOPERASI ELEKTIF DIRUANG BEDAH
}

\section{RELATIONSHIP BETWEEN ANXIETY RATE WITH THE IMPROVEMENT OF BLOOD PRESSURE IN PATIENTS OF ELEKTIF PROPERATION ARE SURGERY}

\author{
Anik Inayati ${ }^{1}$, Sapti Ayubbana ${ }^{2}$ \\ Akademi Keperawatan Dharma Wacana Metro
}

\begin{abstract}
ABSTRAK
Tindakan keperawatan preoperatif merupakan tindakan yang dilakukan oleh perawat dalam rangka mempersiapkan pasien untuk dilakukan tindakan pembedahan dengan tujuan untuk menjamin keselamatan pasien intraoperatif. Pada saat akan menghadapi tindakan operasi yang bukan penderita hipertensi dapat meningkat tekanan darahnya sementara disebabkan oleh 2 faktor yang paling sering terjadi yaitu faktor nyeri, dan faktor kecemasan. Penelitian ini bertujuan untuk mengetahui hubungan tingkat kecemasan dengan peningkatan tekanan darah pada pasien preoperasi elektif. Penelitian ini dengan menggunakan pendekatan cross sectional, metode pengumpulan sampel secara accidental sampling. Sampel penelitian ini adalah 30 pasien preoperasi elektif dengan tidak memiliki riwayat hipertensi. Pengukuran kecemasan menggunakan Hamilton Anxiety Rating Scale dan tekanan darah dengan menggunakan Spymomanometer. Hasil Uji Chi square menunjukkan bahwa terdapat hubungan yang signifikan antara tingkat kecemasan dengan peningkatan tekanan darah ( pvalue $=0,023$ ).

Kata kunci : kecemasan, keperawatan, preoperatif, tekanan darah
\end{abstract}

\begin{abstract}
Preoperative nursing action is an action performed by the nurse in order to prepare the patient for surgical measures in order to ensure the safety of intraoperative patients. When faced with surgery actions that are not hypertensive patients may increase their blood pressure temporarily due to the two most common factors of pain, and anxiety. This study aims to determine the relationship of anxiety levels with increased blood pressure in elective preoperative patients. This research using cross sectional approach, accidental sampling sampling method. The sample of this study were 30 elective preoperative patients with no history of hypertension. Measurement of anxiety using Hamilton Anxiety Rating Scale and blood pressure using Spymomanometer. Chi square test results showed that there is a significant relationship between anxiety levels with an increase in blood pressure (pvalue $=0.023$ ).
\end{abstract}

Keywords: anxiety, nursing, preoperative, blood pressure 


\section{PENDAHULUAN}

Kecemasan merupakan suatu keadaan emosi tanpa suatu objek yang spesifik dan pengalaman subjektif dari individu serta dan tidak dapat diobservasi dan dilihat secara langsung. Kecemasan diartikan sebagai suatu kebingungan, kekhawatiran pada sesuatu yang akan terjadi dengan penyebab atau objek yang tidak jelas dan dihubungkan dengan perasaan tidak menentu dan tidak berdaya. Sebagai contoh kekhawatiran menghadapi operasi/pembedahan (misalnya takut sakit waktu operasi, takut terjadi kecacatan), kekhawatiran terhadap anestesi/ pembiusan (misalnya takut terjadi kegagalan anestesi/ meninggal, takut tidak bangun lagi) ${ }^{1}$.

Carpenito menyatakan $90 \%$ pasien pre operatif berpotensi mengalami kecemasan. Kecemasan (ansietas) merupakan respon psikologik terhadap stres yang mengandung komponen fisiologik dan psikologik. Reaksi fisiologis terhadap kecemasan merupakan reaksi yang pertama timbul pada sistem saraf otonom, meliputi peningkatan frekuensi nadi dan respirasi, pergeseran tekanan darah dan suhu,relaksasi otot polos pada kandung kemih dan usus, kulit dingin dan lembab ${ }^{2}$.

Manifestasi yang khas pada pasien pre operatif tergantung pada setiap individu dan dapat meliputi menarik diri, membisu, mengumpat, mengeluh dan menangis ${ }^{3}$.
Respon psikologis secara umum berhubungan adanya kecemasan menghadapi anestesi, diagnosa penyakit yang belum pasti, keganasan, nyeri, ketidaktahuan tentang prosedur operasi ${ }^{4}$.

Departemen Kesehatan Indonesia pelaksanaan tindakan operasi sebanyak 642.632 pada 401 Rumah Sakit, dengan rincian menurut tingkatan kelas rumah sakit dan data tersebut diklasifikasikan berdasarkan jenis operasi yaitu pada kelas A operasi besar sebanyak $104.106(16,2 \%)$, kelas B operasi besar sebanyak 127.241 (19,8\%), pada kelas C operasi besar sebanyak 154.232 (24\%), dan pada kelas D operasi besar sebanyak 257.053 $(40 \%)^{5}$.

Dinas Kesehatan Propinsi Lampung menyatakan bahwa dari 9 rumah sakit umum daerah didapatkan pelaksanaan tindakan operasi sebanyak 6.678, dengan tindakan operasi tertinggi di RSUD Abdul Moeloek Provinsi Lampung sebanyak 2.467 (36,51\%) tindakan. Dan tingkat kejadian operasi RSUD Jend. Ahmad Yani Metro menempati posisi kedua tertinggi sebanyak $1.297 \quad(19,1 \%)$ tindakan ${ }^{6}$.

Kegagalan akibat tindakan operasi disebabkan oleh tekanan darah meningkat bersamaan dengan kelainan fisiologi organ lainnya seperti sistem pernapasan (nafas pendek, dan rasa tercekik), dan sistem 
pencernaan : hilang nafsu makan, mual, rasa tak enak pada epigastrium, diare. Peningkatan tekanan darah pada saat akan dilakukan operasi elektif disebabkan adanya penyakit hipertensi, faktor kecemasan, dan kurangnya informasi atas tindakan operasi yang akan dilakukan.

Rumah sakit merupakan salah satu organisasi kesehatan dengan segala fasilitas kesehatannya diharapkan dapat membantu pasien dalam meningkatkan kesehatan dan mencapai kesembuhan baik fisik, psikis, maupun sosial. Kecamasan merupakan perasaan yang paling umum dialami oleh pasien yang dirawat dirumah sakit, kecemasan yang sering terjadi adalah apabila pasien yang dirawat dirumah sakit mengalami proses pembedahan ${ }^{7}$.

Berdasarkan uraian diatas, maka dari itu peneliti tertarik untuk mengidentifikasi hubungan tingkat kecemasan dengan peningkatan tekanan darah. Penelitian ini bertujuan untuk mengetahui hubungan tingkat kecemasan dengan peningkatan tekanan darah pada pasien praoperasi elektif di Ruang Bedah RSUD Jend. Ahmad Yani Kota Metro.

\section{METODE}

Desain penelitian ini bersifat korelasi dengan menggunakan pendekatan cross sectional. Metode pengumpulan sampel secara accidental sampling. Sampel penelitian ini adalah 30 pasien preoperasi elektif dengan tidak memiliki riwayat hipertensi. Penelitian dilakukan diruang bedah RSUD Ahmad Yani Metro. Pengukuran kecemasan menggunakan Hamilton Anxiety Rating Scale dan tekanan darah dengan menggunakan Spymomanometer. Data yang didapat dianalisis dengan menggunakan spss versi 21 secara univariate, bivariate (Chi square).

\section{HASIL}

Data karakteristik responden yang didapat adalah menunjukan bahwa dari 30 responden didapatkan usia pasien termuda yaitu usia 18 tahun $(6,7 \%)$, usia tertua yaitu usia 82 tahun $(3,3)$ persen sedangkan rerata pasien berusia 50,2 tahun. Analisis univariat distribusi frekuensi tingkat kecemasan pasien praoperatif elektif dapat dilihat pada tabel berikut ini :

\section{Tabel 1.}

Distribusi Frekuensi Tingkat Kecemasan Pasien Pasien Praoperasi Elektif di RSUD Jend. Ahmad Yani Kota Metro

Tingkat

Kecemasan Frekuensi Prosentase (\%)

\begin{tabular}{lcc}
$\begin{array}{l}\text { Ringan- } \\
\text { Sedang } \\
\text { Berat-Berat } \\
\text { Sekali }\end{array}$ & 13 & 43,3 \\
& 17 & 56,7 \\
\hline Jumlah & 30 & 100 \\
\hline
\end{tabular}


Hubungan tingkat kecemasan dengan tekanan darah pada pasien preoperatif elektik dapat dilihat pada tabel

Tabel 2.

Hubungan Tingkat Kecemasan dengan Tekanan Darah pada Pasien Preoperasi Elektif di RSUD Jend. Ahmad Yani Kota Metro

\begin{tabular}{|c|c|c|c|c|c|c|c|}
\hline \multirow[t]{3}{*}{ No } & Tingkat & & $\begin{array}{l}\text { Tekal } \\
\text { Daral }\end{array}$ & & & \multirow[t]{3}{*}{$\begin{array}{l}\mathrm{p} \\
\text { value }\end{array}$} & \multirow[t]{3}{*}{ OR } \\
\hline & \multirow{2}{*}{ Kecemasan } & & rmal & Hipe & tensi & & \\
\hline & & $\mathrm{n}$ & $\%$ & $\mathrm{n}$ & $\%$ & & \\
\hline 1 & $\begin{array}{l}\text { Ringan- } \\
\text { Sedang }\end{array}$ & 5 & $\begin{array}{l}38, \\
5\end{array}$ & 8 & 5 & 0,023 & $\overline{0,893}$ \\
\hline 2 & $\begin{array}{l}\text { Berat-Berat } \\
\text { Sekali }\end{array}$ & .7 & $\begin{array}{l}41, \\
2\end{array}$ & 10 & $\begin{array}{l}58, \\
8 \\
\end{array}$ & & \\
\hline & Jumlah & 12 & 40 & 18 & 60 & & \\
\hline
\end{tabular}

Tabel 2 menunjukkan bahwa responden memiliki tingkat kecemasan ringan-sedang, sebagian besar mengalami hipertensi yaitu sebesar $61,5 \%$ dan responden yang memiliki tingkat kecemasan berat-berat sekali sebagian besar memiliki tekanan darah hipertensi yaitu sebesar 58,8\%. Hasil uji bivariat antara Tingkat Kecemasan dengan Tekanan Darah didapat nilai $P$-Value 0,023 yang berarti ada hubungan tingkat kecemasan dengan tekanan darah. Sedangkan odd rasio/ faktor resiko (OR) yaitu 0,893 artinya responden yang memiliki tingkat kecemasan berat-berat sekali mempunyai kemungkinan 0,893 kali untuk terjadi Hipertensi.

\section{PEMBAHASAN}

Hasil analisis univariat menunjukkan bahwa 17 responden $(56,7 \%)$ yang mengalami kecemasan berat dan 13 responden $(43,3 \%)$ mengalami kecemasan ringan-sedang.

Kecemasan adalah respon terhadap situasi tertentu yang mengancam, dan merupakan hal yang normal terjadi menyertai perkembangan, perubahan, pengalaman baru atau yang belum pernah dilakukan, serta dalam menemukan identitas diri dan arti hidup ${ }^{8}$.

Operasi merupakan tindakan pembedahan pada suatu bagian tubuh. Operasi (elektif atau kedaruratan) pada umumnya merupakan peristiwa kompleks yang menegangkan. Perioperatif adalah suatu istilah gabungan yang mencakup tiga fase pengalaman pembedahan-praoperatif, intraoperatif, dan pascaoperatif ${ }^{9}$.

Tekanan darah adalah tekanan dari aliran darah dalam pembuluh nadi (arteri). Jantung berdetak 60 hingga 70 kali dalam 1 menit pada kondisi istirahat (duduk atau berbaring), darah dipompa memuju dan melalui arteri. Tekanan darah paling tinggi terjadi ketika jantung berdetak memompa darah, ini disebut tekanan sistolik dan tekanan darah menurun saat jantung rileks diantara dua denyut nadi, ini disebut tekanan diastolik. Tekanan darah ditulis sebagai tekanan sistolik per tekanan diastolik (sebagai contoh, 120/80) ${ }^{10}$.

Hasil analisis bivariat didapatkan bahwa $\mathrm{p}$ value 0,023 yang berarti bahwa ada hubungan tingkat kecemasan dengan tekanan darah pada pasien praoperasi elektif di RSUD Jend. Ahmad Yani Kota Metro Tahun 2015. 
Berdasarkan teori bahwa tindakan Preoperatif adalah fase dimulai ketika keputusan untuk menjalani operasi atau pembedahan dibuat dan berakhir ketika pasien dipindahkan ke meja operasi . Fase preoperasi merupakan peristiwa kompleks yang menegangkan ${ }^{9}$.

Kecemasan merupakan perasaan takut yang tidak jelasdan tidak didukung oleh situasi hal ini dapat menimbulkan berbagai respon fisiologi salah satunya adalah peningkatan tekanan darah. Meningkatnya tekanan darah akan mengganggu operasi karena bias menyebabkan pendarahan dan bisa menggagalkan penatalaksanaan operasi ${ }^{11}$.

Ketakutan dan kecemasan yang sangat berlebihan, akan membuat klien menjadi tidak siap secara emosional untuk menghadapi pembedahan, dan akan menghadapi masalah praoperatif seperti Tertundanya operasi karena tingginya denyut nadi perifer dan mempengaruhi palpasijantung ${ }^{12}$.

Pasien akan mengalami tanda-tanda fisiologis seperti peningkatan tekanan darah. Jika tekanan darah yang meningkat tidak segera diatasi, itu bisa menjadi salah satu penyebab terhalangnya kegiatan operasi, tekanan darah standart yang bisa menjadi pedoman untuk pelaksanaan kegiatan di ruang premedikasi dan sebelum pasien diputuskan untuk dianastesi adalah dengan standart 150 hingga dengan $160 \mathrm{mmHg}$ untuk sistolik dan 90-100 mmHg untuk diastolik ${ }^{13}$.

\section{KESIMPULAN DAN SARAN}

Hasil penelitian ini menunjukkan bahwa terdapat hubungan secara signifikan antara tingkat kecemasan pada pasien praoperasi dengan tekanan darah pada pasien praoperasi elektif di RSUD Jend. Ahmad Yani Kota Metro tahun 2015 dengan nilai p value 0,023. Penelitian lanjutan tentang pemberian intervensi keperawatan untuk mengurangi kecemasan pada pasien preoperatif.

\section{DAFTAR PUSTAKA}

1. Suliswati, 2005. Konsep dasar keperawatan jiwa.Jakarta : EGC

2.Carpenito, 2006. Buku Saku Keperawatan Edisi III. Jakarta : EGC

3. Long, Barbara, 2006. Perawatan medical bedah jilid III. Padjadjaran : IAPK

4. Silvia,2010. Rasa takut dan ansietas,www//http:sivalintar.com.ansietas. htm

5. DepKes RI, 2012. Angka kejadian tindakan pembedahan indonesia. www.kesehatan.com, 2013

6. Dinas Kesehatan Propinsi Lampung, 2012. Profil kesehatan provinsi lampung www.kasdu.com.

7. Asmadi, 2008. Konsep dasar keperawatan. Jakarta : EGC

8. Fauziah dan Julianti Widuri, 2007. Sistem instalasi gawat darurat. Jakarta : Dunia Pustaka Jaya

9. Smeltzer dan Bare, 2005. Buku ajar Keperawatan bedah. Jakarta : EGC 
